\title{
Sosialisasi Pembuatan Dan Manfaat Hand Sanitizer Daun Sirih Untuk Aplikasi Pencegahan Penularan Covid-19
}

\author{
Hasrin Lamote, Zul Arham*, Ismaun Ismaun \\ Institut Agama Islam Negeri (IAIN) Kendari
}

\begin{abstract}
ABSTRAK
Kegiatan ini dilakukan untuk memberikan pembinaan dan pengetahuan kepada siswa dan guru Madrasah Aliyah (MA) DDI Al-Ihsan Kendari tentang proses pembuatan dan manfaat hand sanitizer daun sirih untuk aplikasi pencegahan penularan coronavirus disease 19 (Covid-19). Metode pelaksanaan kegiatan terdiri dari Focus Group Discussion (FGD) dan praktek pembuatan cairan hand sanitizer. Luaran dari kegiatan yaitu siswa dan guru mendapat pengetahuan berdasarkan data-data penelitian terbaru tentang potensi tanaman sirih sebagai bahan antimikroorganisme seperti bakteri dan virus. Selain itu, siswa secara mandiri dapat membuat hand sanitizer di rumah atau di sekolah. Selama kegiatan berlangsung siswa dan guru banyak memberikan respon positif melalui tanya jawab baik pada kegiatan FGD maupun kegiatan praktek.
\end{abstract}

Kata kunci: Covid-19, daun sirih, hand sanitizer, MA DDI Al-Ihsan

\section{Socialization of Making and Benefits of Betel Leaf Hand Sanitizer For Transmission Prevention Applications of Covid-19}

\begin{abstract}
This activity was carried out to provide guidance and knowledge to students and teachers of Madrasah Aliyah (MA) DDI Al-Ihsan Kendari about the making process and benefits of the betel leaf hand sanitizer for the application of preventing the transmission of coronavirus disease 19 (Covid-19). The method of implementing the activity consisted of a Focus Group Discussion (FGD) and the practice of making hand sanitizer fluids. The output of the activity is that students and teachers get knowledge based on the latest research data on the potential of the betel plant as an antimicroorganism such as bacteria and viruses. In addition, students can independently make hand sanitizers at home or at school. During the activity, students and teachers gave many positive responses through question and answer both in FGD activities and practical activities.
\end{abstract}

Keywords: Covid-19, betel leaf, hand sanitizer, MA DDI Al-Ihsan

Penulis Korespondensi :

Zul Arham

Program Studi Tadris IPA, IAIN Kendari

E-mail : arhamzul88@yahoo.com

No. Hp : 085210505393 


\section{PENDAHULUAN}

Coronavirus disease (Covid-19) merupakan jenis penyakit yang disebabkan oleh Coronavirus jenis baru yaitu SARS-CoV-2. Keberadaan Covid-19 berawal dari sekelompok kasus pneumonia virus yang terjadi di Wuhan, Provinsi Hubei-Cina, sejak Desember 2019 (Yuliana, 2020). Berdasarkan data kasus yang ditemukan, Covid-19 tidak memberikan dampak yang begitu besar dengan angka kematian kecil. Dimana hingga tanggal 19 Januari 2020 hanya terjadi 2 kematian dari 198 kasus yang dilaporkan di Wuhan. Data ini menjadi acuan WHO dan pemerintah Indonesia secara khusus dalam menetapkan kebijakan pencegahan penularan Covid19 (Abdillah, 2020). Akan tetapi, penularan Covid-19 yang terjadi begitu cepat di Indonesia, khususnya pada bulan maret dengan angka kematian 4 orang dari 69 kasus menyebabkan permasalahan baru bagi pemerintah dan masyarakat (Handayani, Hadi, Isbaniah, Burhan, \& Agustin, 2020).

Permasalahan di atas mendapat respon yang beragam dari masyarakat terkait upaya pencegahan penularan Covid-19. Usaha pencegahan yang dilakukan antara lain menghindari kontak fisik seperti jabat tangan dan memperbanyak mencuci tangan dikarenakan tangan menjadi sarana percepatan penularan mikroorganisme seperti mikroba dan virus. Selain sabun, hand sanitizer menjadi pilihan lain yang penggunaannya dilaporkan meningkat secara signifikan. Hand Sanitizer merupakan antiseptik pembersih tangan yang digunakan sebagai alternatif pengganti sabun (Liu, Yuen, Hsiao, Jaykus, \& Moe, 2010). Beberapa keunggulan hand sanitizer antara lain penggunaan yang simpel, mudah disimpan, dan efektif membunuh mikroorganisme di tangan dalam waktu relatif cepat (Rini, Supartono, \& Wijayati, 2017).

Penggunaan hand sanitizer yang meningkat memberi dampak terhadap ketersediaan dan harga penjualan di pasaran. Dimana, ketersedian hand sanitizer yang terbatas di pasaran, menjadikan harga penjualan juga meningkat. Hal ini mendorong masyarakat melakukan inovasi dalam menyediakan hand sanitizer, diantaranya adalah pembuatan hand sanitizer berbahan alam seperti daun sirih. Pemilihan daun sirih didasarkan pada beberapa pertimbangan yaitu bahan baku yang melimpah di masyarakat, harga produksi murah, dan kandungan senyawa bioaktif dalam daun sirih efektif menghambat pertumbuhan atau membunuh mikroorganisme. Beberapa hasil penelitian yang telah dilaporkan yaitu manfaat ekstrak daun sirih (Piper bettle Linn) sebagai hand sanitizer untuk menurunkan angka kuman tangan (Hapsari, Hendrarini, \& Muryani, 2019), formulasi infusan daun sirih merah (Piper crocatum) sebagai gel antiseptik tangan (Prabowo, Widayat, \& Defriana, 2018), formulasi dan aktivitas antibakteri gel hand sanitizer ekstrak air daun sirih merah (Milala, Umami, \& Wahjudi, 2016), formulasi minyak atsiridaun sirih hijau (Piper betle L.) dalam sediaan gel pencuci tangan (Opilia, 2016), studi efektivitas sediaan gel antiseptik tangan ekstrak daun sirih (Piper betle Linn.) (Sari \& Isadiartuti, 2006). 
Dalam kegiatan pengabdian ini, kami melakukan sosialisasi pembuatan dan manfaat hand sanitizer yang dibuat dari ekstrak daun sirih di sekolah Madrasah Aliyah (MA) DDI Al-Ihsan Kendari. Pemilihan sekolah ini didasarkan pada dua hal yaitu : (i) saat ini wilayah sekolah dan sekitarnya berada dalam status green zone, sehingga perlu upaya mempertahankan status ini, dan (ii) pada kondisi new normal, siswa dan guru masih melakukan aktifitas belajar mengajar secara tatap muka dengan tetap memperhatikan protokol Covid-19.

\section{METODE}

\section{Pelaksanaan Focus Group Discussion} (FGD)

Kegiatan FGD dilakukan antara tim pengabdi bersama siswa dan guru
MA DDI Al-Ihsan Labibia. FGD diawali dengan penyampaian materi tentang potensi daun sirih sebagai anti bakteri dan virus, kemudian dilanjutkan dengan penyampaian tahapan pembuatan hand sanitizer, dan diakhiri dengan tanya jawab antara tim pengabdi dan peserta.

\section{Pelatihan Pembuatan Hand Sanitizer Daun Sirih}

$$
\text { Pelatihan pembuatan hand }
$$
sanitizer daun sirih dilakukan dengan mengacu pada tahapan kerja seperti yang ditunjukan pada Gambar 1.

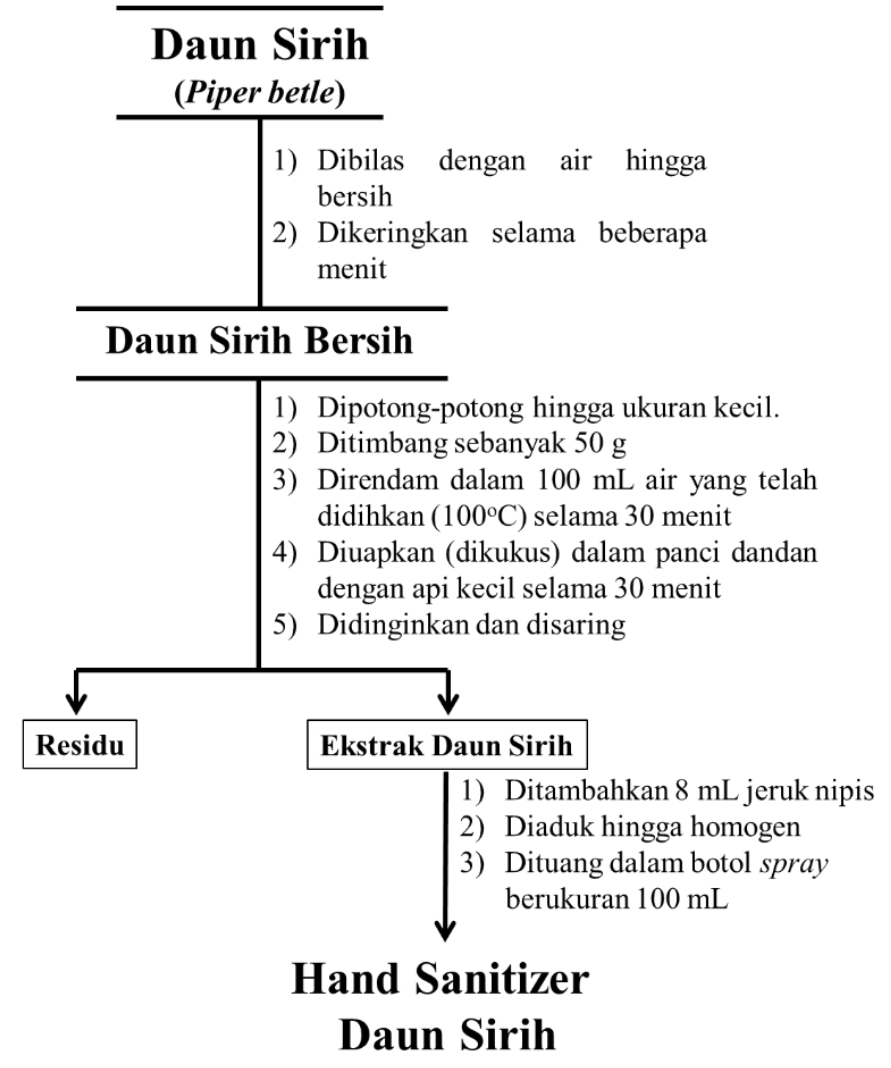

Gambar 1. Tahapan pembuatan hand sanitizer daun sirih (Adinda, Nur Sholikah \& Riva Ismawati, 2020). 


\section{HASIL DAN PEMBAHASAN}

\section{Gambaran Umum Lokasi Pengabdian}

Madrasah Aliyah (MA) DDI AlIhsan terletak di kelurahan Labibia, kecamatan Mandonga, kota Kendari. Di masa pandemi Covid-19, wilayah ini masuk dalam kategori green zone. Jarak antara IAIN Kendari dengan lokasi pengabdian berkisar $20 \mathrm{~km}$, dengan waktu tempuh berkisar 30-40 menit. Gambar 2 menunjukan peta lokasi pengabdian dan kondisi sekolah.

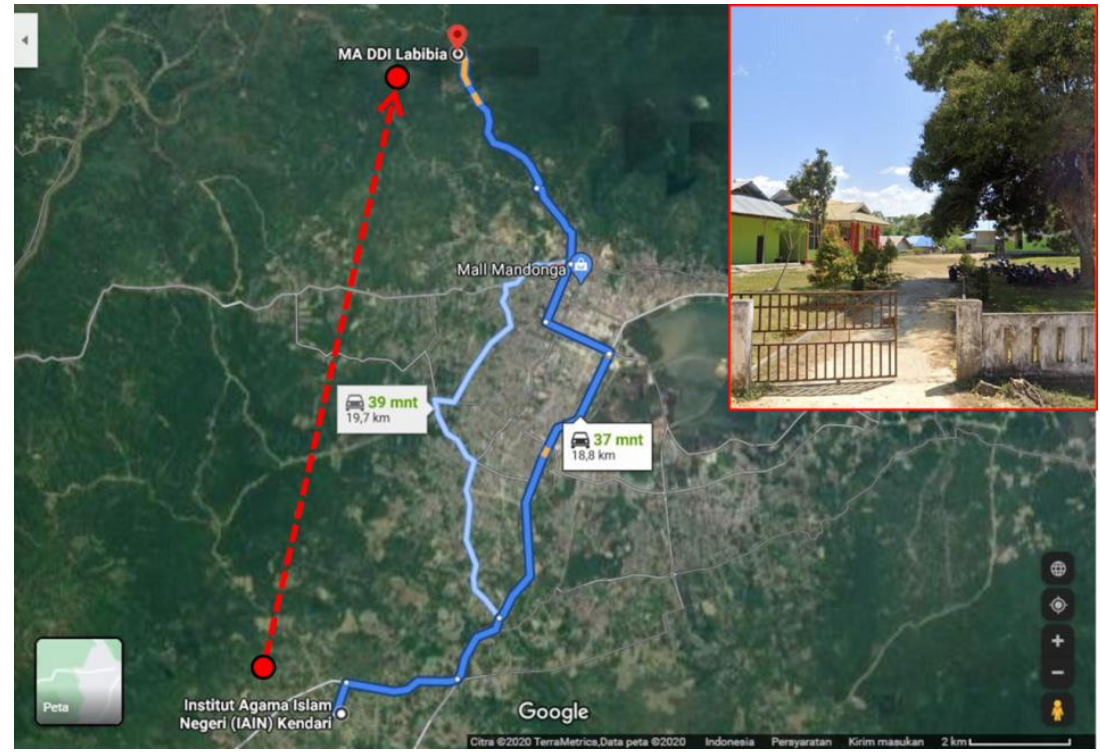

Gambar 2. Peta lokasi kegiatan pengabdian.

Saat ini, MA DDI Al-Ihsan kendari dipimpin oleh bapak Bahrin, S.Pd.I., MA, dan dibantu oleh bapak Rusman, S.Ag., MA (Waka Kurikulum), bapak Sahrun, S.Pd.I (Waka Kesiswaan), bapak Yaco, S.Pd (Waka Sarana), dan bapak Halil, S.Pd.I (Pembina OSIS). Jumlah guru dan siswa dalam kegiatan ini secara berturut-turut yaitu 17 dan 78 orang. Sebelum pelaksanaan FGD dan praktek pembuatan daun sirih, baik siswa maupun guru belum mempunyai pengetahuan dasar tentang pembuatan hand sanitizer.

\section{Pelaksaan Focus Group Discussion}

Pelaksanaan FGD yang dilakukan terdiri dari dua tahapan kegiatan yaitu : (i) penyampaian materi tentang hand sanitizer dan potensi tanaman sirih sebagai bahan hand sanitizer, dan (ii) penyampaian panduan pembuatan hand sanitizer daun sirih. Penyampaian materi (Gambar 3a) diawali dengan memberikan pengetahuan umum kepada peserta FGD tentang fungsi, bahan dasar yang umum digunakan, dan pengembangan teknologi terbaru dalam produksi hand sanitizer. Materi dilanjutkan dengan menjelaskan potensi bahan-bahan alam (natural product) sebagai bahan alternatif untuk pencegahan penularan virus atau bakteri, jenis-jenis natural product yang dapat dimanfaatkan, kandungan kimia yang umum terdapat pada natural product sebagai dasar pemanfaatannya sebagai anti virus maupun bakteri. 
Penyampaian materi ditutup dengan penjelasan tentang potensi dan tantangan penggunaan daun sirih sebagai hand sanitizer alternatif dimasa pandemi Covid-19.

Pada kegiatan FGD kedua (penyampaian panduan pembuatan hand sanitizer) (Gambar 3b), prinsip penting dalam pembuatan hand sanitizer daun sirih yang disampaikan mencakup : (1) tahap penyiapan; (2) tahap ekstraksi, dan (3) tahap penyimpanan. Tahap penyiapan secara umum terdiri dari pemilihan daun sirih, pencucian, pengeringan, dan perajangan. Pemilihan daun sirih berdasarkan kesegaran daun, hal ini dimaksudkan untuk mendapatkan jumlah senyawa bioaktif yang lebih banyak. Pencucian daun sirih menggunakan air bersih, sedangkan pengeringan dapat dilakukan pada suhu ruang maupun pengeringan menggunakan oven dengan kisaran suhu $60-80^{\circ} \mathrm{C}$. Suhu ini diasumsikan tidak merusak struktur senyawa bioaktif dari daun sirih. Penjarangan merupakan proses akhir dari tahap penyiapan. Penjarangan dimaksudkan untuk menjadikan permukaan daun sirin menjadi lebih luas, sehingga proses pengambilan senyawa bioaktif (proses ekstraksi) menjadi lebih optimal. Penjarangan diupayakan mendapatkan daun sirih dengan ukuran sekecil mungkin.

Tahap ekstraksi menjadi tahap yang sangat ditekankan untuk dipahami oleh peserta. Ekstraksi merupakan tahap mendapatkan senyawa bioaktif daun sirih berdasarkan sifat kelarutan dan kepolaran. Dalam FGD ini, tim pengabdi menjelaskan dua hal penting yaitu : (i) peranan pelarut saat ekstraksi, dan (ii) pengaruh suhu ekstraksi. Pelarut yang digunakan dalam pembuatan hand sanitizer daun sirih yaitu air. Air memiliki peranan penting dalam proses ekstraksi, dimana air mempunyai sifat kepolaran yang baik sehingga efektif menarik senyawa bioaktif yang bersifat polar. Selain itu, ketersedian air yang melimpah, dan mudah ditemukan. Proses ekstraksi senyawa bioaktif daun sirih dilakukan dengan cara merendam daun sirih dalam air panas yang dilanjutkan dengan pengukusan selama 30 menit. Pengukusan menggunakan suhu rendah untuk mencegah kerusakan senyawa bioaktif.
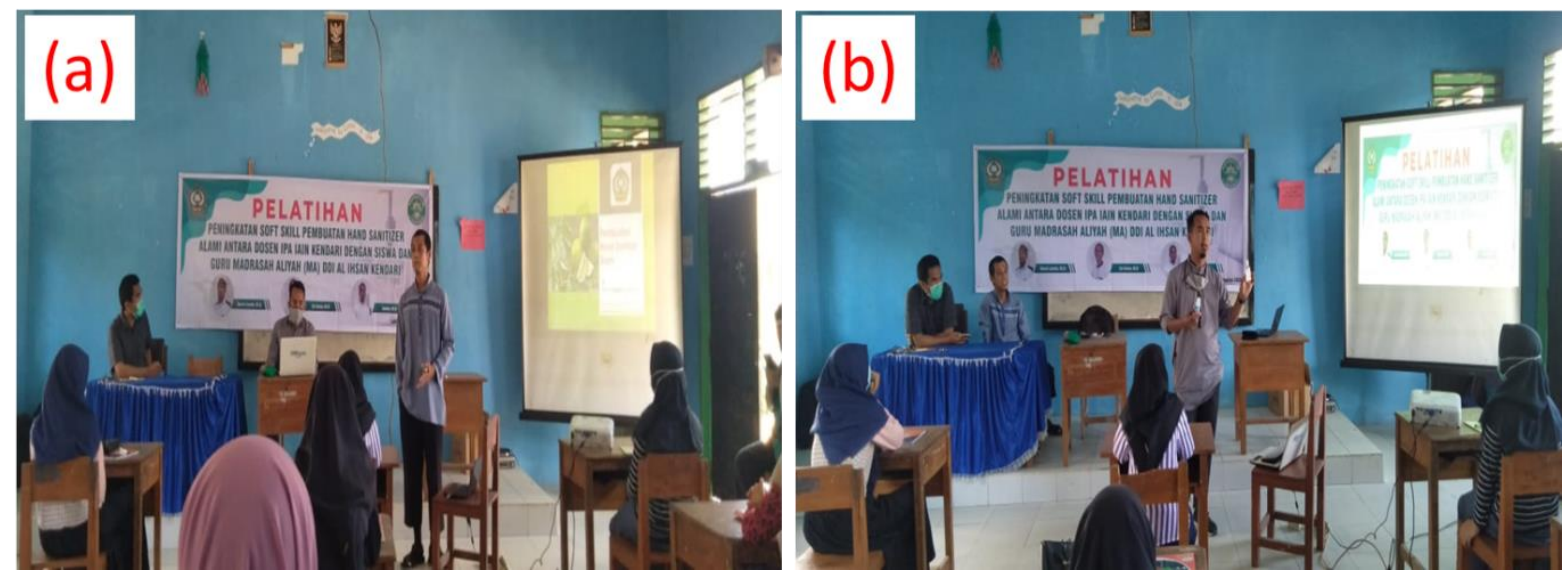
Gambar 3. Kegiatan FGD tim pengabdi bersama siswa dan guru MA DDI Al-Ihsan Labibia : (a) Penyampaian materi; (b) pengantar praktek pembuatan hand sanitizer daun sirih.

\section{Pembuatan Hand Sanitizer Daun Sirih}

Pembuatan hand sanitizer daun sirih diawali dengan menjelaskan bahan dan peralatan yang digunakan (Gambar 4a). Bahan yang digunakan yaitu daun sirih segar berukuran sedang, jeruk nipis, dan air. Sedangkan peralatan yang digunakan yaitu pisau, corong pemisah, wadah penampung berupa gelas kimia dan erlenmeyer, gelas ukur, dan alat pemanas. Wadah ini umumnya digunakan pada skala laboratorium, adapun skala rumah dapat menggunakan lain seperti panci dandan dan kompor. Gambar 4b menunjukan cara penyiapan daun sirih baik pemilihan daun, pencucian, maupun cara penjarangan yang benar. Gambar 4c menunjukan proses pemisahan ekstrak daun sirih yang diperoleh setelah tahap pengukusan. Pemisahan yang baik sangat ditentukan dari ukuran pori dari penyaring yang digunakan.
Dalam pelatihan ini, pemisahan ekstrak daun sirih dilakukan menggunakan kertas saring. Hasil pemisahan dapat dilihat pada Gambar 4d. Ekstrak daun sirih berwarna kuning dengan sedikit aroma khas daun sirih. Pembentukan warna kuning disebabkan sifat senyawa bioaktif daun sirih yang mudah teroksidasi, sehingga untuk meminimalkan terbentuknya warna kuning dilakukan penambahan ekstrak jeruk nipis. Penambahan ekstrak jeruk nipis mempunyai dua fungsi yaiti (i) mencegah senyawa bioaktif daun sirih teroksidasi, hal ini disebabkan adanya kandungan asam askorbat, dan (ii) menambah efektifitas anti virus atau mikroba dari ekstrak daun sirih, dimana ekstrak jeruk nipis juga dilaporkan mengandung senyawa bioaktif yang dapat menghambat pertumbuhan mikroorganisme. 



Gambar 4. Pembuatan hand sanitizer daun sirih : (a) pengenalan bahan dan peralatan; (b) penyiapan daun sirih; (c) pemisahan cairan ekstrak; dan (d) ekstrak daun sirih.

\section{KESIMPULAN}

Kegiatan sosialisasi pembuatan dan manfaat hand sanitizer daun sirih di Sekolah Madrasah Aliyah DDI Al-Ihsan Kendari telah sukses dilaksanakan. Metode pelaksaan kegiatan yang terdiri dari focus group discussion dan praktek pembuatan hand sanitizer efektif menambah : (i) pengetahuan siswa dan guru tentang hand sanitizer dan potensi tanaman alam (natural product) seperti daun sirih sebagai bahan alternatif, dan (ii) ketrampilan (soft skill) siswa dan guru dalam pembuatan hand sanitizer alam. Hand sanitizer yang dibuat dalam kegiatan ini selanjutnya akan dimanfaatkan oleh siswa dan guru selama berada dilingkungan sekolah. Hand sanitizer daun sirih yang dibuat dalam kegiatan ini belum dapat dikomersialkan, akan tetapi telah dapat dimanfaatkan untuk kebutuhan perorangan dan keluarga. Hand sanitizer daun sirih masih memerlukan pengembangan lanjutan khususnya untuk pemanfaatan sebagai anti Covid19.

\section{UCAPAN TERIMA KASIH}

Kami ucapkan banyak terima kasih kepada pimpinan Fakultas Tarbiyah dan Ilmu Keguruan IAIN Kendari yang memberikan izin penyelenggaraan kegiatan. Selain itu, ucapan banyak terima kasih juga kami sampaikan kepada kepala sekolah Madrasah Aliyah (MA) DDI Al-Ihsan Kendari beserta jajarannya yang telah mendukung kegiatan ini.

\section{DAFTAR PUSTAKA}

Abdillah, L. A. (2020). Stigma Terhadap Orang Positif COVID-19. In: Pandemik COVID-19: Antara Persoalan dan Refleksi di Indonesia. Yayasan Kita Menulis, Medan, pp. 11-24. ISBN 978-623-7645-71-9. 
Adinda, P. P. E., Nur, S., \& Riva, I. (2020). Pembuatan Hand Sanitizer Alami Dengan Memanfaatkan Tumbuhan Saun Sirih Di RW 04 Desa Setia Mekar. ADIPPAJA: Jurnal Pengabdian Kepada Masyarakat, 1 (1), 29-35.

Handayani, D., Hadi, D. R., Isbaniah, F., Burhan, E., \& Agustin, H. (2020). Corona Virus Disease 2019. Jurnal Respirologi Indonesia, 40(2), 119-129.

Hapsari, D. N., Hendrarini, L., \& Muryani, S. (2019). Manfaat Ekstrak Daun Sirih (Piper betle Linn) Sebagai Hand Sanitizer Untuk Menurunkan Angka Kuman Tangan. Jurnal Kesehatan Lingkungan, 7(2), 79-84.

Liu, P., Yuen, Y., Hsiao, H.-M., Jaykus, L.-A., \& Moe, C. (2010). Effectiveness of liquid soap and hand sanitizer against Norwalk virus on contaminated hands. Applied and Environmental Microbiology, 76(2), 394-399.

Milala, A. S., Umami, T. W. R., \& Wahjudi, M. (2016). Formulasi dan Aktivitas Antibakteri Gel Hand Sanitizer Ekstrak Air Daun Sirih Merah.
Opilia, T. (2016). Formulasi Minyak Atsiri Daun Sirih Hijau (Piper bettle L.) dalam Sediaan Gel Pencuci Tangan. Jurnal FARMAKU (Farmasi Muhammadiyah Kuningan), 1(1), 24-31.

Prabowo, W. C., Widayat, W., \& Defriana, S. (2018). Formulasi Infusan Daun Sirih Merah (Piper crocatum) Sebagai Gel Antiseptik Tangan. Jurnal Sains Dan Kesehatan, 1(10), 525-530.

Rini, A. R. S., Supartono, S., \& Wijayati, N. (2017). Hand Sanitizer Ekstrak Kulit Nanas sebagai Antibakteri Staphylococcus aureus dan Escherichia coli. Indonesian Journal of Chemical Science, 6(1), 61-66.

Sari, R., \& Isadiartuti, D. (2006). Studi efektivitas sediaan gel antiseptik tangan ekstrak daun sirih (Piper betle Linn.). Majalah Farmasi Indonesia, 17(4), 163-169.

Yuliana, Y. (2020). Corona virus diseases (Covid-19): Sebuah tinjauan literatur. Wellness And Healthy Magazine, 2(1), 187-192. 